\title{
Advanced Techniques in Biology \& Medicine
}

\section{Is Storytelling Therapy Useful for Children with Autism Spectrum Disorders and Severe Mental Retardation?}

\author{
Fabienne Giuliani ${ }^{1 *}$, Béatrice Couchepin Marchetti ${ }^{1}$, Viviane Perrenoud ${ }^{2}$ and Pierre El Korh ${ }^{1}$ \\ ${ }^{1}$ Psychiatry and Mental Development Department (Community Psychiatry Service, Psychiatry Department), University Hospital of Lausanne, Switzerland \\ ${ }^{2}$ Etablissement de l'association Le FOYER, Lausanne, Switzerland
}

\begin{abstract}
Numerous studies highlight the importance of therapeutic context when learning social skills for young ASD patients. Therapy approaches become more complex when the situation involves young ASD patients with a severe mental disability. Indeed, when working with this population, it is difficult to get their attention and have them mimic actions (through video modeling, for example) or interact with peers on a playground. Nevertheless, our study tried to demonstrate the possibility of working on the social skills of young ASD patients with a severe mental disability using a therapeutic storytelling approach. The study involved 10 children (average age of $10.6+/-2$ years). All study participants were diagnosed with ASD and severe mental retardation. 62 sessions divided across two years and twenty repeated assessments were taken during this study, and the results obtained show that the children learned, in a significant way, to imitate the story's actions. They also significantly reduced their behavioral issues. A physiological assessment (eye-tracking) was taken both pre and post-test during the storytelling workshop. The results obtained confirmed a significant increase in attention given to the storytelling scene.
\end{abstract}

Keywords: Autism spectrum disorders; Intellectual disabilities; Storytelling therapy; Eye-tracking

\section{Introduction}

Autism spectrum disorders (ASD) refer to a cluster of symptoms characterized by a qualitative impairment in reciprocal social interactions and in communication, to a restricted, repetitive and stereotyped pattern to behavior, interests and activities, to a delay or abnormal character to functioning that begins in childhood, as well as the presence of sensory hypersensitivity. Currently, ASD fall on a continuum of functioning that includes mild to severe mental retardation, including the absence of mental retardation, as well as mild to severe autistic behaviors. Much research focuses on the qualitative impairments in communication and reciprocal social interactions. This is because pharmaceutical treatment has yet to be proven effective against this [1] and so in recent years, strategies for treatment have been oriented toward improving social skills $[2,3]$. Social skills essentially rely on processing interpersonal clues and the ability to effectively interpret these clues in order to respond appropriately [4,5]. As [6] have mentioned, children with ASD do not have the social skills that enable them to develop in an appropriate way in our highly social world [7]. Numerous studies have shown that this kind of social impairment is coming from a difficulty in tracking a moving object [8] and an inability to process faces [9-13]. Nevertheless, some studies have shown that it is possible to address this deficit [14-17]. Numerous studies highlight the importance of therapeutic context when learning social skills for young ASD patients. It appears that the most effective are video modeling and approaches involving mediating peers $[1,14,18-21]$. A therapeutic intervention becomes more complex when the situation involves young ASD patients with a severe mental disability. Indeed, when working with this population, it is difficult to get their attention and have them mimic actions (through video modeling, for example) or interact with peers on a playground. Nevertheless, our study tried to demonstrate the possibility of working on the social skills of young ASD patients with a severe mental disability through a workshop dedicated to storytelling.

\section{Methods and Materials}

\section{Participants}

Ten children participated in the study. There were 7 boys and 3 girls, between the ages of 7 and 13 (average $10.6+/-2$ years). The participants were all diagnosed with ASD and severe mental retardation according to the Diagnostic and Statistical Manuel of Mental Disorders, $4^{\text {th }}$ Edition criteria [22], confirmed by a clinical psychologist specialized in ASD and corroborated by the CARS (Childhood Autism Rating Assessment Scale) [23]. Intellectual functioning was measured with the PEP-R [24] and showed very low developmental ages. The Swiss Ethics Commission authorized the study. Following a detailed explanation of the research protocol, written informed consent was obtained from the parents for the study and publication of the results. Consent was obtained by the participating children. The workshop took place in a specialized school for children with ASD and mental disabilities. To increase objectivity, evaluations, behavioral coding and eye-tracking measurements were conducted by independent evaluators who were not school faculty.

The severity of the autistic disorders was catalogued in the following table, according to DSM-V classification [25] (Table 1).

\section{Storytelling workshop}

The workshop was based on Therapeutic Storytelling [26], a promising approach whose effectiveness we wanted to evaluate with children with autism spectrum disorders and a severe mental handicap. The workshop teaches 10 fundamental goals which are incorporated through direct teaching. The fundamental goals and the targeted behaviors are: (1) provide social support (establish confidence, reduce stress); (2) create a pleasant environment (facilitate social play); (3) create a dynamic model of social interaction (social

*Corresponding author: Fabienne Giuliani, Site de Cery, 1008 Prilly, Switzerland, Tel: +41213142185; E-mail: fabienne.Giuliani@chuv.ch

Received February 02, 2016; Accepted February 08, 2016; Published February 15,2016

Citation: Giuliani F, Marchetti BC, Perrenoud V, El Korh P (2016) Is Storytelling Therapy Useful for Children with Autism Spectrum Disorders and Severe Mental Retardation? Adv Tech Biol Med 4: 166. doi: 10.4172/2379-1764.1000166

Copyright: $\odot 2016$ Giuliani F, et al. This is an open-access article distributed under the terms of the Creative Commons Attribution License, which permits unrestricted use, distribution, and reproduction in any medium, provided the original author and source are credited. 
Citation: Giuliani F, Marchetti BC, Perrenoud V, El Korh P (2016) Is Storytelling Therapy Useful for Children with Autism Spectrum Disorders and Severe Mental Retardation? Adv Tech Biol Med 4: 166. doi: 10.4172/2379-1764.1000166

Page 2 of 5

\begin{tabular}{|c|c|c|c|c|c|c|c|c|c|c|}
\hline \multicolumn{11}{|c|}{ Selected Diagnostic Criteria } \\
\hline & Child 1 & Child 2 & Child 3 & Child 4 & Child 5 & Child 6 & Child 7 & Child 8 & Child 9 & Child 10 \\
\hline Sex & Female & Female & Female & Male & Male & Male & Male & Male & Male & Male \\
\hline Age & 12 years & 13 years & 8 years & 13 years & 10 years & 13 years & 12 years & 9 years & 7 years & 9 years \\
\hline GAF & Scale 10 & Scale 10 & Scale 10 & Scale 31 & Scale 21 & Scale 31 & Scale 31 & Scale 31 & Scale 41 & Scale 41 \\
\hline \multicolumn{11}{|c|}{ Persistent difficulties in communication and interactions } \\
\hline $\begin{array}{l}\text { Socio-emotional } \\
\text { reciprocity }\end{array}$ & $\begin{array}{l}\text { Level } 3^{*} \\
\text { Very substantial } \\
\text { support }\end{array}$ & $\begin{array}{l}\text { Level } 3 \\
\text { Very substantial } \\
\text { support }\end{array}$ & $\begin{array}{l}\text { Level } 3 \\
\text { Very substantial } \\
\text { support }\end{array}$ & $\begin{array}{l}\text { Level } 3 \\
\text { Very substantial } \\
\text { support }\end{array}$ & \begin{tabular}{|l|} 
Level 3 \\
Very substantial \\
support
\end{tabular} & $\begin{array}{l}\text { Level } 3 \\
\text { Very substantial } \\
\text { support }\end{array}$ & $\begin{array}{l}\text { Level } 3 \\
\text { Very substantial } \\
\text { support }\end{array}$ & $\begin{array}{l}\text { Level } 3 \\
\text { Very substantial } \\
\text { support }\end{array}$ & $\begin{array}{l}\text { Level } 3 \\
\text { Very substantial } \\
\text { support }\end{array}$ & $\begin{array}{l}\text { Level } 3 \\
\text { Very substantial } \\
\text { support }\end{array}$ \\
\hline $\begin{array}{l}\text { Non-verbal } \\
\text { communication } \\
\text { impairment }\end{array}$ & $\begin{array}{l}\text { Level } 3 \\
\text { Very substantial } \\
\text { support }\end{array}$ & $\begin{array}{l}\text { Level } 3 \\
\text { Very substantial } \\
\text { support }\end{array}$ & $\begin{array}{l}\text { Level } 3 \\
\text { Very substantial } \\
\text { support }\end{array}$ & $\begin{array}{l}\text { Level } 3 \\
\text { Very substantial } \\
\text { support }\end{array}$ & \begin{tabular}{|l|} 
Level 3 \\
Very substantial \\
support
\end{tabular} & $\begin{array}{l}\text { Level } 3 \\
\text { Very substantial } \\
\text { support }\end{array}$ & $\begin{array}{l}\text { Level } 3 \\
\text { Very substantial } \\
\text { support }\end{array}$ & $\begin{array}{l}\text { Level } 3 \\
\text { Very substantial } \\
\text { support }\end{array}$ & $\begin{array}{l}\text { Level } 3 \\
\text { Very substantial } \\
\text { support }\end{array}$ & $\begin{array}{l}\text { Level } 3 \\
\text { Very substantial } \\
\text { support }\end{array}$ \\
\hline $\begin{array}{l}\text { Difficulty in } \\
\text { developing, } \\
\text { maintaining and } \\
\text { understanding age- } \\
\text { appropriate social } \\
\text { relationships }\end{array}$ & $\begin{array}{l}\text { Level } 3 \\
\text { Very substantial } \\
\text { support }\end{array}$ & $\begin{array}{l}\text { Level } 3 \\
\text { Very substantial } \\
\text { support }\end{array}$ & $\begin{array}{l}\text { Level } 3 \\
\text { Very substantial } \\
\text { support }\end{array}$ & $\begin{array}{l}\text { Level } 3 \\
\text { Very substantial } \\
\text { support }\end{array}$ & $\begin{array}{l}\text { Level } 3 \\
\text { Very substantial } \\
\text { support }\end{array}$ & $\begin{array}{l}\text { Level } 3 \\
\text { Very substantial } \\
\text { support }\end{array}$ & $\begin{array}{l}\text { Level } 3 \\
\text { Support }\end{array}$ & $\begin{array}{l}\text { Level } 3 \\
\text { Very substantial } \\
\text { support }\end{array}$ & $\begin{array}{l}\text { Level } 3 \\
\text { Very substantial } \\
\text { support }\end{array}$ & $\begin{array}{l}\text { Level } 3 \\
\text { Very substantial } \\
\text { support }\end{array}$ \\
\hline \multicolumn{11}{|c|}{ Stereotyped behaviors and restricted interests } \\
\hline $\begin{array}{l}\text { Use of repetitive/ } \\
\text { stereotyped gestures }\end{array}$ & $\begin{array}{l}\text { Level } 3 \\
\text { Very substantial } \\
\text { support }\end{array}$ & $\begin{array}{l}\text { Level } 3 \\
\text { Very substantial } \\
\text { support }\end{array}$ & $\begin{array}{l}\text { Level } 1 \\
\text { Mild impairment }\end{array}$ & $\begin{array}{l}\text { Level } 1 \\
\text { Mild impairment }\end{array}$ & $\begin{array}{l}\text { Level } 1 \\
\text { Mild impairment }\end{array}$ & $\begin{array}{l}\text { Level } 2 \\
\text { Substantial } \\
\text { support }\end{array}$ & $\begin{array}{l}\text { Level } 2 \\
\text { Substantial } \\
\text { support }\end{array}$ & $\begin{array}{l}\text { Level } 2 \\
\text { Substantial } \\
\text { support }\end{array}$ & $\begin{array}{l}\text { Level } 1 \\
\text { Mild impairment }\end{array}$ & $\begin{array}{l}\text { Level } 1 \\
\text { Mild impairment }\end{array}$ \\
\hline $\begin{array}{l}\text { Insistance on } \\
\text { similarity of routines } \\
\text { and verbal or non- } \\
\text { verbal rituals }\end{array}$ & $\begin{array}{l}\text { Level } 3 \\
\text { Very substantial } \\
\text { support }\end{array}$ & $\begin{array}{l}\text { Level } 3 \\
\text { Very substantial } \\
\text { support }\end{array}$ & $\begin{array}{l}\text { Level } 2 \\
\text { Substantial } \\
\text { support }\end{array}$ & $\begin{array}{l}\text { Level } 2 \\
\text { Substantial } \\
\text { support }\end{array}$ & $\begin{array}{l}\text { Level } 2 \\
\text { Substantial } \\
\text { support }\end{array}$ & $\begin{array}{l}\text { Level } 2 \\
\text { Substantial } \\
\text { support }\end{array}$ & $\begin{array}{l}\text { Level } 2 \\
\text { Substantial } \\
\text { support }\end{array}$ & $\begin{array}{l}\text { Level } 2 \\
\text { Substantial } \\
\text { support }\end{array}$ & $\begin{array}{l}\text { Level } 2 \\
\text { Substantial } \\
\text { support }\end{array}$ & $\begin{array}{l}\text { Level } 2 \\
\text { Substantial } \\
\text { support }\end{array}$ \\
\hline $\begin{array}{l}\text { Restricted, limited or } \\
\text { atypical interests in } \\
\text { terms of intensity and } \\
\text { type of interest }\end{array}$ & $\begin{array}{l}\text { Level } 3 \\
\text { Very substantial } \\
\text { support }\end{array}$ & $\begin{array}{l}\text { Level } 3 \\
\text { Very substantial } \\
\text { support }\end{array}$ & $\begin{array}{l}\text { Level } 2 \\
\text { Substantial } \\
\text { support }\end{array}$ & $\begin{array}{l}\text { Level } 2 \\
\text { Substantial } \\
\text { support }\end{array}$ & $\begin{array}{l}\text { Level } 2 \\
\text { Substantial } \\
\text { support }\end{array}$ & $\begin{array}{l}\text { Level } 2 \\
\text { Substantial } \\
\text { support }\end{array}$ & $\begin{array}{l}\text { Level } 2 \\
\text { Substantial } \\
\text { support }\end{array}$ & $\begin{array}{l}\text { Level } 2 \\
\text { Substantial } \\
\text { support }\end{array}$ & $\begin{array}{l}\text { Level } 2 \\
\text { Substantial } \\
\text { support }\end{array}$ & $\begin{array}{l}\text { Level } 2 \\
\text { Substantial } \\
\text { support }\end{array}$ \\
\hline $\begin{array}{l}\text { Hyper or Hypo } \\
\text { reactivity to sensory } \\
\text { stimuli }\end{array}$ & $\begin{array}{l}\text { Level } 3 \\
\text { Severe } \\
\text { impairment }\end{array}$ & $\begin{array}{l}\text { Level } 3 \\
\text { Severe } \\
\text { impairment }\end{array}$ & $\begin{array}{l}\text { Level } 1 \\
\text { Mild impairment }\end{array}$ & $\begin{array}{l}\text { Level } 1 \\
\text { Mild impairment }\end{array}$ & $\begin{array}{l}\text { Level } 1 \\
\text { Mild impairment }\end{array}$ & $\begin{array}{l}\text { Level } 1 \\
\text { Mild impairment }\end{array}$ & $\begin{array}{l}\text { Level } 1 \\
\text { Mild impairment }\end{array}$ & $\begin{array}{l}\text { Level } 1 \\
\text { Mild impairment }\end{array}$ & $\begin{array}{l}\text { Level } 1 \\
\text { Mild impairment }\end{array}$ & $\begin{array}{l}\text { Level } 1 \\
\text { Mild impairment }\end{array}$ \\
\hline
\end{tabular}

*Level of impairment from $0=$ no support; $1=$ support; $2=$ substantial support; $3=$ very substantial support

Table 1: Description of the children as well as their level of impairment according to the DSM-V.

interaction with peers); (4) strengthen motivation (increase personal and shared initiative); (5) engage in directed communication (improve communication); (6) use non-verbal communication (improve eye contact, facial expressions and gestures); (7) engage in play (develop imitation); (8) use empathy-based responses (develop empathy); (9) support active learning (encourage novelty and participation); and (10) foster individual learning (integrate targeted behaviors into learning).

The workshop was held for two years, once a week for two hours (10:00-12:00), for a total of 62 sessions divided across two years. The story given to the children was the three little pigs.

For the first part of the workshop, a teacher told a story. The story's gestures were slowed down and indicated by the teacher who then asked the students to reproduce the gestures (imitation) while listening to the storyteller. In the second part of the workshop, the students were asked to play-out the various roles of the story. To develop their imagination and empathy, the children wore dress-up costumes.

In the third part of the workshop, the costumes were hung on a line and the children were asked to take them and associate them with a role. Throughout the two years of the workshop, the children had to take on different story roles; they were not allowed to limit themselves to a single role.

\section{Behavioral assessments}

We used two scales to evaluate behaviors:

The ABC scale [27] which is a questionnaire with 58 questions and which highlights 5 types of problematic behaviors (stereotyped, hyperactivity, irritability, lethargy and language disorders). We conducted 20 repeated assessments.

- A checklist of 63 behavioral goals to achieve during the story.
The observation was carried out through time-based sampling, every 20 minutes. The observer noted the absence or presence of an imitated behavior according to a list of determined behaviors in order to study the child's activity or passivity level.

Scoring was done by giving a 1 when the gesture was carried out during the story and a 0 when it wasn't. We obtained an average of imitated gestures per session, $0=$ no imitated movements; $1=63$ imitated movements. Here is the list of achieved behaviors (Table 2).

\section{Social functioning assessment}

We used the GAF at the beginning and at the end of the study to evaluate changes in the children's functioning.

\section{Assessment of visual scanning: Eye-tracking}

The study used the Mobile Eye XG from Applied Science Laboratories in Bedford, USA. Eye-tracking quantifies the length of the individual's fixation points. This parameter enabled us to measure the attention granted to a watched scene by a given child. Interested readers can find more information regarding this parameter and the device used in the articles published by the same author [28-30]. The goal of using this device was to evaluate the evolution of visual contact for each child between his or her first exposure to the therapeutic story and the last session at the end of the study (pre-test and post-test evaluation).

It is known that ASD children have imitative skills but that they have difficulties with eye tracking. Research conducted in visual scanning shows a specificity for such scanning in people with autism spectrum disorders compared to the norm-such as difficulties in eye contact during social interactions, in eye tracking of a dynamic target, in precision and rapidity in spatial representations as well as atypical saccades [31-36]. It is also known that ASD individuals are competent in terms of learning 
Citation: Giuliani F, Marchetti BC, Perrenoud V, El Korh P (2016) Is Storytelling Therapy Useful for Children with Autism Spectrum Disorders and Severe Mental Retardation? Adv Tech Biol Med 4: 166. doi: 10.4172/2379-1764.1000166

Page 3 of 5

\begin{tabular}{|c|c|c|c|c|}
\hline \multicolumn{5}{|c|}{ List of gestures reproduced by the students and expected during the story } \\
\hline pig & Creak (a $2^{\text {nd }}$ time) & knock & stamp feet & angry wolf \\
\hline house & Hello Mister & No, No, you cannot come into my house & knock at the door & climb \\
\hline quiet & House $\left(\mathrm{a} 4^{\text {th }}\right.$ time $)$ & Blow (a $2^{\text {nd }}$ time $)$ & $\begin{array}{l}\text { No, No, you cannot come into } \\
\text { my house }\end{array}$ & go down \\
\hline strong & close the door (a $3^{\text {th }}$ time $)$ & stamp feet & blow and eat all three & pot \\
\hline intelligent & creak $\left(a 3^{\text {rd }}\right.$ time $)$ & run & blow storm & light \\
\hline goodbye mom & wolf & close the door ( $4^{\text {th }}$ time $)$ & solid house & go down \\
\hline cry & mean & turn the key & angry wolf & clap hands \\
\hline Hello Mister & angry & Wolf (a $3^{\text {th }}$ time $)$ & blow(a $4^{\text {th }}$ time $)$ & sing \\
\hline House (a $2^{\text {nd }}$ time) & blow & angry $\left(a 2^{\text {nd }}\right.$ time $)$ & storm (a $2^{\text {nd }}$ time $)$ & scared song... \\
\hline close the door & storm & knock on the door & solid & ending gesture you \\
\hline Creak & run & wolf sentence & wolf idea & laughing at joke \\
\hline house(a $3^{\text {th }}$ time $)$ & house (a $5^{\text {th }}$ time) & pig sentence & 5 o'clock watch & \\
\hline close the door (a $2^{\text {nd }}$ time $)$ & wolf(a $2^{\text {nd }}$ time $)$ & blow (a $3^{\text {th }}$ time $)$ & 6 o'clock watch & \\
\hline
\end{tabular}

Table 2: List of 63 words spoken and gestured by the storyteller and for which we expected an imitative gesture from the children. Scoring was done by giving a 1 when the gesture was carried out and a 0 when it wasn't.

through observation, imitation and modeling [37,38] but they must be assisted with specific approaches, which is why we wanted to evaluate whether the storytelling workshop offered to these children enabled them to specifically improve their observation and imitative skills.

\section{Statistical analysis}

This research used the methodology of individual cases [39], which means studying the changes in each child through repeated, timebased assessments. 31 assessments are catalogued in this article, one assessment for every two sessions. The child thus becomes his or her own witness and we evaluate the child across distinct phases, including a baseline (A) and a workshop phase (B). We also conducted a group analysis by summing the results obtained for all the children. A repeated measure ANOVA was performed for the Behavioral Assessments. A paired t-test was conducted to evaluate the children's visual scanning.

\section{Results}

\section{Goal achievement}

Based upon independent evaluators using the 63 objective checklist (reproducing the 63 gestures of the story), the ASD children demonstrated a significant increase in active participation with peers. The repeated measure ANOVA showed a significant effect, $\mathrm{F}(9,19)$ $=6.367, p<0.0001)$. Our results confirm that storytelling can improve social skills and support the following five goals on ten: (5) engage in directed communication (improve communication); (6) use nonverbal communication (improve eye contact, facial expressions and gestures); (7) engage in play (develop imitation); (9) support active learning (encourage novelty and participation); and (10) foster individual learning (integrate targeted behaviors into learning). (pre $=2,77$ $\mathrm{SD}=1,64$; post $=3.00 \mathrm{SD}=1.41, p=0,553$ ) (Figure 1).

\section{Problematic behaviors (ABC)}

We noted a significant reduction in problematic behaviors, as shown by the repeated measure ANOVA, F $(19,10450)=281.418, p<0.0001)$. This suggests that the children demonstrated an improvement in their capacity to adapt and, accordingly, of the following objectives (five goals on ten): (1) provide social support (establish confidence, reduce stress); (2) create a pleasant environment (facilitate social play); (3) create a model of dynamic social interaction (social interaction with peers); (5) engage in directed communication (improve communication) and (7) engage in play (develop imitation) (Figure 2).

\section{Social functioning (GAF)}

In terms of evaluating social functioning, a significant difference was found for the social functioning scale between the pre-test (mean 25.7, $\mathrm{SD}=3.86$ ) and the post-test (mean 35.8 $\mathrm{SD}=4.19, P<0.0001)$. According to these results, we were able to confirm our hypothesis in terms of an improvement in social functioning (Figure 3).

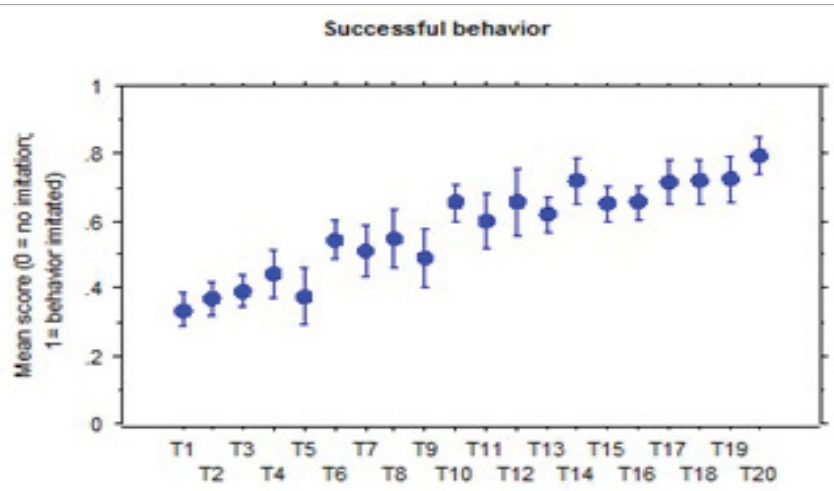

Figure 1: Average number of imitated gestures during the storytelling workshop.

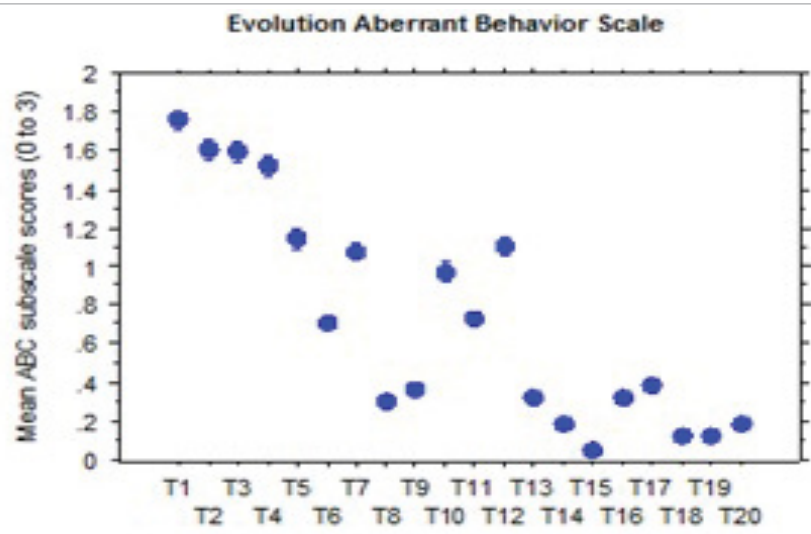

Figure 2: Average of problematic behaviors noted during the storytelling workshop. 


\section{Eye-tracking}

The eye-tracking measurements made it possible to quantitatively assess the children's visual progress in terms of the percentage of time spent watching the storytelling workshop (the duration of the fixation points). This evaluation showed a significant increase in the time spent watching the workshop between the pre-test (mean $34.77, \mathrm{SD}=2.71$ ) and the post-test (mean 61.42, $\mathrm{SD}=2.86, P=0.0006$ ). Our results corroborate the achievement of the following one goal on ten (6) use nonverbal communication (improve eye contact, facial expressions and gestures) (Figure 4).

\section{Discussion}

The fundamental goals of the storytelling workshop were all achieved, i.e.: (1) provide social support (establish confidence, reduce stress); (2) create a pleasant environment (facilitate social play); (3) create a dynamic model of social interaction (social interaction peers); (4) strengthen motivation (increase personal and shared initiative); (5) engage in directed communication (improve communication); (6) use non-verbal communication (improve eye contact, facial expressions and gestures); (7) engage in play (develop imitation); (8) use empathy-based responses (develop empathy); (9) support active learning (encourage novelty and participation); and (10) foster individual learning (integrate targeted behaviors into learning).

The ASD students all showed a significant improvement in their perception of the storytelling scenes. They also improved their capacity to identify and remember facial stimuli; this was measured by the goal achievement evaluation grid.

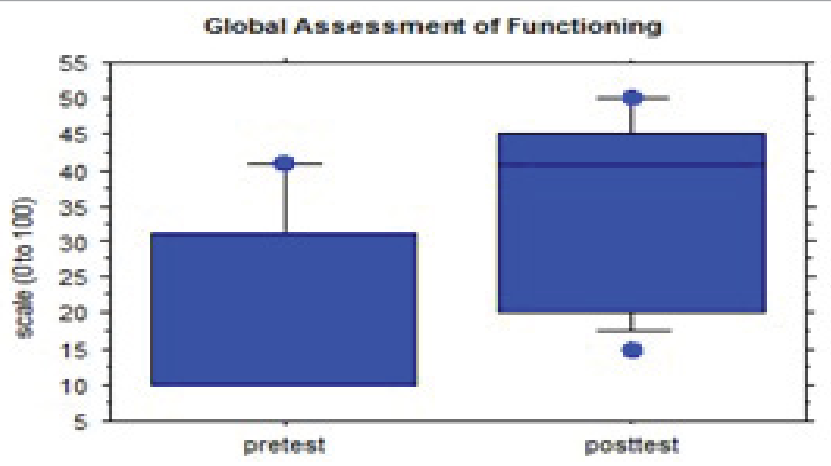

Figure 3: GAF comparison between the pre- and post-test.

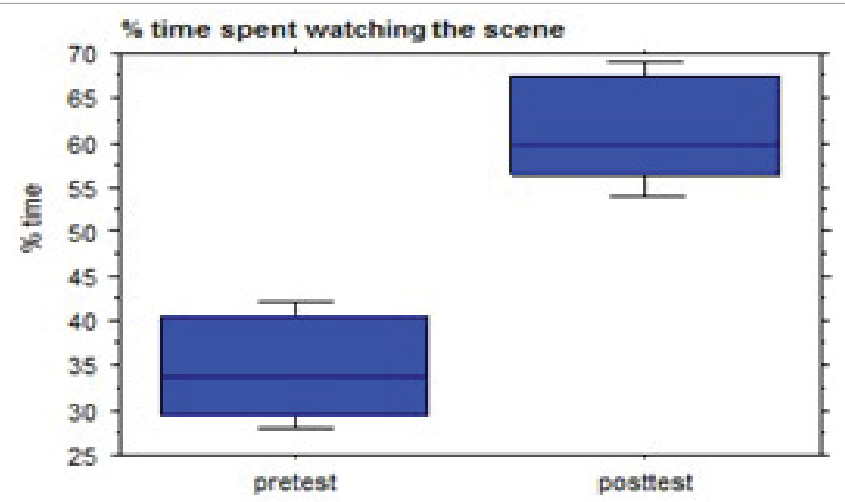

Figure 4: Comparison of \% of visual scanning spent watching the storytelling workshop between the pre-test and the post-test.
The positive results we found in terms of the possibility of improving the social skills of children with severe cognitive impairments and ASDs has also been demonstrated by other authors $[1,15]$.

However, while there are numerous studies showing that the visual processing of faces is altered in autism (for example, [10-12] few studies have shown an improvement of this social skill following a therapeutic intervention $[16,17,40]$.

In our study, the improvement of social perception was also observed through the reduction of behavioral problems as well as by an improvement in visual scanning. We can infer that the face-toface contact and active practice of reciprocal social interaction with peers contributed to the improvement of perceptive skills. Our study supports Corbett's hypothesis [14] that social perception seems to require explicit training in order to be learned.

The systematic intervention of the storytelling workshop appears to be useful for improving social perception, cognitive skills and social interactions. However, a more extensive intervention could be necessary in order to facilitate the transfer of skills to daily life.

To determine the impact of the intervention on daily life, the Global Assessment of Functioning scale was used as well as the problematic behavior scale. The functioning scale brought out a positive evolution in terms of the transfer of skills to daily life following the intervention. This significant evolution might be explained by the generalization of skills learned during the storytelling workshop into the environment.

The strong points of this study include the intervention itself, which combines the behavioral techniques established by the story and the promising theatrical approach which made it possible for the children to practice social skills with their peers. The use of diverse scales made it possible to completely evaluate the ASD children during treatment in their natural setting. The improvement in social perception was corroborated by the use of various tools and methods.

Despite its encouraging results, the limitations of the study include its small sample size. Group comparisons would strengthen our conclusions. It is clear that additional studies are needed to corroborate the results highlighted in this study and to examine the importance of peer interaction as well as sensitivity to stress. The optimal level of interaction, the length of the treatment, and the limits of skills generalization are further steps. Future studies will also make it possible to evaluate the important contributing factors to the improvements observed in terms of the social functioning of ASD participants. Further studies will enable a more specific way of identifying the most effective components of the intervention by comparing it with and without key elements in another storytelling workshop. It seems likely that the peer aspect of the workshop lies at the heart of the intervention's effectiveness. Essentially, the use of a peer-mediator has been shown to be an effective strategy for improving the skills of individuals with ASDs [41]. We also believe that the theatrical approach (including the scripted social engagement) of a theatrical play followed by improvisation games, with an active participation in reciprocal social interaction, provides an effective support basis for working on social skills.

Considering the improvement in visual scanning as well as the reduction in problematic behaviors during the two years of the intervention, several questions remain open. For example, will the positive effects hold over time or are they a positive reinforcement produced by the storytelling workshop? In other words, are the improvement in visual scanning and the reduction of problematic behaviors a result of a modification in perceptive and cognitive 
Citation: Giuliani F, Marchetti BC, Perrenoud V, El Korh P (2016) Is Storytelling Therapy Useful for Children with Autism Spectrum Disorders and Severe Mental Retardation? Adv Tech Biol Med 4: 166. doi: 10.4172/2379-1764.1000166

Page 5 of 5

processing or, conversely, are they the result of conditioning linked to systematic use during two years of the storytelling workshop? The second would indicate a transitory state that will lessen over time.

Only a longitudinal study with a group comparison would be able to answer this question.

In conclusion, our study confirms the effectiveness of the workshop and corroborates other studies which highlight a theatrical group intervention with peer-mediators $[1,15]$. This study also brought to light a gain in adaptive functioning.

\section{References}

1. Corbett BA, Swain DM, Coke C, Simon D, Newsom C, et al. (2014) Improvement in social deficits in autism spectrum disorders using a theatre-based, peermediated intervention. Autism Res 7: 4-16.

2. Thommen E, Cartier-Nelles B, Guidoux A, Wiesendanger S (2014) Les particularités cognitives dans le trouble du spectre de l'autisme. Swiss Archives of Neurology and Psychiatry 165: 290-297.

3. Wink LK, Erickson CA, McDougle CJ (2010) Pharmacologic treatment of behavioral symptoms associated with autism and other pervasive developmental disorders. Curr Treat Options Neurol 12: 529-538.

4. Constantino JN, Przybeck T, Friesen D, Todd RD (2000) Reciprocal socia behavior in children with and without pervasive developmental disorders. J Dev Behav Pediatr 21: 2-11.

5. Gresham FM (1986) Conceptual and definitional issues in the assessment of children's social skills: Implications for classification and training. Journal of Clinical Child Psychology 15: 3-15.

6. Knott F, Dunlop AW, Mackay T (2006) Living with ASD: how do children and their parents assess their difficulties with social interaction and understanding? Autism 10: 609-617.

7. Krasny L, Williams BJ, Provencal S, Ozonoff S (2003) Social skills interventions for the autism spectrum: essential ingredients and a model curriculum. Child Adolesc Psychiatr Clin N Am 12: 107-122.

8. Gepner B, Féron F (2009) Autism: a world changing too fast for a mis-wired brain? Neurosci Biobehav Rev 33: 1227-1242.

9. Adolphs R, Sears L, Piven J (2001) Abnormal processing of social information from faces in autism. J Cogn Neurosci 13: 232-240.

10. Corbett BA, Carmean V, Ravizza S, Wendelken C, Henry ML, et al. (2009) A functional and structural study of emotion and face processing in children with autism. Psychiatry Res 173: 196-205.

11. Critchley HD, Daly EM, Bullmore ET, Williams SC, Van Amelsvoort T, et al. (2000) The functional neuroanatomy of social behaviour: changes in cerebral blood flow when people with autistic disorder process facial expressions. Brain 123: 2203-2212.

12. Pierce K, Müller RA, Ambrose J, Allen G, Courchesne E (2001) Face processing occurs outside the fusiform 'face area' in autism: evidence from functional MRI. Brain 124: 2059-2073.

13. Schultz RT, Gauthier I, Klin A, Fulbright RK, Anderson AW, et al. (2000) Abnormal ventral temporal cortical activity during face discrimination among individuals with autism and Asperger syndrome. Arch Gen Psychiatry 57: 331 340

14. Corbett BA (2003) Video Modeling: a window into the world of autism. The Behavior Analyst Today 4: 367-377.

15. Corbett BA, Gunther JR, Comins D, Price J, Ryan N, et al. (2011) Brief report: theatre as therapy for children with autism spectrum disorder. J Autism Dev Disord 41: 505-511.

16. Faja S, Webb SJ, Jones E, Merkle K, Kamara D, et al. (2012) The effects of face expertise training on the behavioral performance and brain activity of adults with high functioning autism spectrum disorders. Journal of Applied Behavior Analysis 25: 265-280.

17. Tanaka JW, Wolf JM, Klaiman C, Koenig K, Cockburn J, et al. (2010) Using computerized games to teach face recognition skills to children with autism spectrum disorder: the Let's Face It! program. J Child Psychol Psychiatry 51: 944-952.
18. Charlop-Christy MH, Le L, Freeman KA (2000) A comparison of video modeling with in vivo modeling for teaching children with autism. J Autism Dev Disord 30: $537-552$

19. Kamps D, Royer J, Dugan E, Kravits T, Gonzalez-Lopez A, et al. (2002) Peer training to facilitate social interaction for elementary students with autism and their peers. Exceptional Children 68: 173-187.

20. Nikopoulos CK, Keenan M (2007) Using video modeling to teach complex social sequences to children with autism. J Autism Dev Disord 37: 678-693.

21. Reichow B, Volkmar FR (2010) Social skills interventions for individuals with autism: evaluation for evidence-based practices within a best evidence synthesis framework. J Autism Dev Disord 40: 149-166.

22. DSM-IV (2000) DSM-IV-TR: diagnostic and statistical manual of mental disorders. American Psychiatric Association, Washington, DC.

23. Schopler E, Reichler RJ, Rochen Renner B (1986) The childhood autism rating scale (CARS): For diagnostic screening and classification of autism (Diagnosis and teaching curricula for autism and developmental disabilities). Irvington, New York.

24. Schopler E (1994) Profil Psycho-éducatif (PEP-R). In: C Trehin, Trans De Boeck, Larcier SA (edr) De Boeck and Larcier, Bruxelles.

25. DSM-V (2013) DSM-V: Diagnostic and Statistical Manual of Mental Disorders American Psychiatric Association, Washington, DC.

26. Lafforgue P (2002) Petit Poucet deviendra grand: Soigner avec le conte. Payot and Rivage, Paris.

27. Rojahn J, Aman MG, Matson JL, Mayville E (2003) The Aberrant Behavio Checklist and the Behavior Problems Inventory: convergent and divergent validity. Res Dev Disabil 24: 391-404.

28. Giuliani F, Favrod J, Bonsack C, Schenk F (2009) Organisation de l'exploration oculaire dans le cadre d'un traitement de l'évitement du contact visuel TCC et neurosciences. Issy-les-Moulineaux: Elsevier Masson.

29. Giuliani F, Favrod J, Grasset F, Schenk F (2011) Accurate memory for object location by individuals with intellectual disability: absolute spatial tagging instead of configural processing? Res Dev Disabil 32: 986-994.

30. Giuliani F, Perrenoud V, Favrod J (2014) Using eye-tracking as support for the TEACCH program and two teenagers with autism-spectrum disorders. Revue Francophone de Clinique Comportementale et Cognitive XIX: 39-56.

31. Berthoz A (2005) L'échange par le regard L'autisme: De la recherche à la pratique. Odile Jacob, Paris.

32. Itier RJ, Batty M (2009) Neural bases of eye and gaze processing: the core of social cognition. Neurosci Biobehav Rev 33: 843-863.

33. Noris B, Nadel J, Barker M, Hadjikhani N, Billard A (2012) Investigating gaze of children with ASD in naturalistic settings. PLoS One 7: e44144.

34. Rice K, Moriuchi JM, Jones W, Klin A (2012) Parsing heterogeneity in autism spectrum disorders: visual scanning of dynamic social scenes in school-aged children. J Am Acad Child Adolesc Psychiatry 51: 238-248.

35. Schaer M, Franchini M, Eliez S (2014) Latest findings in autism research: How do they support the importance of early diagnosis and immediate intervention? Swiss Archives of Neurology and Psychiatry 8: 277-289.

36. Shultz S, Klin A, Jones W (2011) Inhibition of eye blinking reveals subjective perceptions of stimulus salience. Proc Natl Acad Sci U S A 108: 21270-21275

37. Egel AL, Richman GS, Koegel RL (1981) Normal peer models and autistic children's learning. J Appl Behav Anal 14: 3-12.

38. Wolery M, Garfinkle AN (2002) Measures in intervention research with young children who have autism. J Autism Dev Disord 32: 463-478.

39. Bernard C (1865) Introduction à l'étude de la médecine expérimentale. Flammarion, Paris.

40. Corbett BA, Abdullah M (2005) Video Modeling: Why does it work for children with autism? Journal of Early and Intensive Behavior Intervention 2: 2-8.

41. Odom SL, Strain PS (1984) Peer-mediated approaches to promoting children's social interaction: a review. Am J Orthopsychiatry 54: 544-557. 